СТРУКТУРА І ЗМІСТ СИСТЕМИ ПРОФЕСІЙНОЇ ПІДГОТОВКИ МАЙБУТНІХ МАГІСТРІВ МЕДИЦИНИ ДО ПЕДАГОГІЧНОЇ ДІЯЛЬНОСТІ

\title{
STRUCTURE AND CONTENT OF THE SYSTEM OF PROFESSIONAL TRAINING OF FUTURE MASTERS OF MEDICINE FOR PEDAGOGICAL ACTIVITY
}

\begin{abstract}
Динамічна ситуація на ринку праці, інтенсивний розвиток суспільства, інфрорматизація наукового й освітнього простору зобов'язують систему вищої медичної освіти орормувати професійну конкурентоспроможність майбутніх магістрів медицини в умовах сучасності, що передбачає не лише розуміння теоретичних знань, а й здатність застосовувати їх на практиці, високий рівень загального інтелектуального розвитку, ініціативність, мобільність, креативність. Педагогічно правильно організована і методично спланована фундаментальна підготовка майбутніх магістрів медицини стає передумовою забезпечення їхньої чілеспрямованої орієнтації на майбутню педагогічну діяльність в умовах практичного використання теоретичних знань з огляду на стрімкий розвиток медицини.

У статті визначено структуру педагогічно системи підготовки майбутніх магістрів медицини до педагогічної діяльності, що передбачає певну логічну послідовність з урахуванням загальних складників педагогічної системи: визначення мети функціонування педагогічної системи; виконання та представлення змісту навчання з урахуванням вимог до спеціальності випускника (відбір змісту навчання відбувається відповідно до чілей навчання); вибір та розроблення освітніх прочесів; визначення організаційних орорм навчання. Систему підготовки майбутніх магістрів медицини до педагогічної діяльності розглянуто як ієрархію взаємопов'язаних і взаємозумовлених складових елементів, комплекс навчальних і навчально-професійних завдань, підструктур педагогічної діяльності викладачів i навчально-профресійної роботи студентів, що створюють умови для активної профресійно-педагогічної діяльності в інтегрованому освітньому просторі.

На засадах розгляду основних вимог до побудови системи підготовки магістрів медицини до педагогічної діяльності встановлено, що сучасна медична освіта має значний, однак не повною мірою реалізований гуманітарний потенціал, пов'язаний із духовним, моральним, ціннісним, естетичним розвитком студентів.

Ключові слова: магістри медицини, система професійної підготовки, педагогічна діяльність, структура, зміст.
\end{abstract}

The dynamic situation on the labor market, intensive development of society, informatization of scientific and educational space oblige the system of higher medical education to form the professional competitiveness of future masters of medicine in modern conditions, which involves not only understanding theoretical knowledge but also the ability to apply it in practice, high level of general intellectual development, initiative, mobility, creativity. Pedagogically correctly organized and methodically planned fundamental training of future masters of medicine becomes a prerequisite for ensuring their purposeful orientation to future pedagogical activity in terms of practical use of theoretical knowledge given the rapid development of medicine.

In the article there is defined the structure of the pedagogical system of preparation of future masters of medicine for pedagogical activity, which provides a certain logical sequence taking into account the general components of the pedagogical system: determining the purpose of the pedagogical system functioning; implementation and presentation of the content of training, taking into account the requirements for the specialty of the graduate (a selection of the content of training in accordance with the objectives of training); selection and development of educational processes; definition of organizational forms of training. The system of preparation of future masters of medicine for pedagogical activity is considered as a hierarchy of interconnected and interdependent constituent elements, a complex of educational and educational-professional tasks, substructures of pedagogical activity of teachers and educational and professional work of students, creating conditions for active professional and pedagogical activity in the integrated educational space.

On the basis of consideration of the basic requirements for the construction of the system of preparation of masters of medicine for pedagogical activity it is established that modern medical education contains significant, but not fully realized humanitarian potential associated with spiritual, moral, value, aesthetic development of students.

Key words: masters of medicine, system of professional training, pedagogical activity, structure, content.
Постановка проблеми В загальному вигляді. У сучасній медичній освіті з'являються тенденції, що дають змогу говорити про перехід цієї системи в якісно новий стан. Вища медична школа $€$ високотехнологічною системою педагогічного устаткування, електронних засобів навчання, нових умов для реалізації державних освітніх стандартів, інноваційних освітніх технологій. Вона повинна забезпечити випускникам систему інтегрованих теоретичних і клінічних знань, умінь і навичок, допомогти освоїти високі світові медичні технології, сорормувати здатність до соціальної адаптації магістрів медицини. Реалізація таких завдань сприяє цілісній підготовці магістрів медицини до педагогічної діяльності, опирається на міцну мотиваційну настанову, глибоку спеціалізацію, актуалізацію інтелектуальних і особистісних можливостей студентів.

Сучасні напрями розвитку вітчизняної освіти визначають необхідність удосконалення теоретичної і технологічної бази підготовки магістрів медицини до педагогічної діяльності згідно із 
соціальними запитами інфрормаційного суспільства масової комунікації та досягненнями науки і техніки XXI століття. У зв'язку із цим орієнтація освіти на відкритість і мобільність, максимальне задоволення запитів студентів зумовлює зміни в діяльності викладачів закладів вищої медичної освіти, які реалізують процеси навчання, виховання і фрормування особистості майбутніх магістрів медицини в умовах інорорматизації освіти. Водночас зростає роль самостійної навчальної діяльності студентів, що передбачає якісну зміну традиційних форм освітньої діяльності згідно із цілями і завданнями розвитку інтелектуального потенціалу магістрів медицини.

Аналіз останніх досліджень і публікацій. Шляхи вдосконалення вищої медичної освіти в України та розвиток їі змісту, професійних стандартів, системи організації в Україні і за кордоном розглянуто в наукових дослідженнях І. Геленко, Б. Криштопи, Л. Ковальчука, І. Радзієвської, Я. Цехмістера; особливості рефрормування системи оцінювання якості знань студентів закладів вищої медичної освіти аналізували І. Булах, О. Волосовець, М. Мруга; підготовку майбутніх медиків, фрундаментальні питання та технології професійної підготовки розглядали Т. Волосовець, В. Вороненко, М. Гжегоцький, Б. Зіменковський, І. Мельничук, Ю. П'ятницький та ін. Ключові проблеми професійної підготовки студентів медичних спеціальностей, зокрема в контексті компетентнісного підходу, висвітлено в наукових публікаціях О. Андрійчук, П. Бабенко, Н. Жуковської, К. Куренкової, С. Пудової. Специфіка знаково-символьної реальності кібер- та інтернет-простору висвітлена в дослідженнях $€$. Белінської, В. Беспалько, А. Горіної, А. Мудрика, В. Ушакової та ін.

Виділення не вирішених раніше частин загальної проблеми. Попри значну різноманітність дослідницьких праць, проблема побудови системи підготовки майбутніх магістрів медицини до педагогічної діяльності в закладах медичної освіти малорозроблена, що зумовило необхідність її поглибленого вивчення.

Мета статті. На основі використання системної методології метою статті визначено розкриття змісту і структури системи підготовки майбутніх магістрів медицини до педагогічної діяльності, що визначається ії складовими елементами в цільовій взаємодії, у якій аксіоматично вбудована предметна сорера навчання.

Виклад основного матеріалу. Побудова системи професійної підготовки майбутніх магістрів медицини до педагогічної діяльності $€$ своєрідним способом пізнання. Водночас сама система $€$ певним стандартом (зразком) послідовності дій викладача і студента, зорієнтованих на вирішення спільних завдань у підготовці майбутніх магістрів медицини до педагогічної діяльності.
Профресійна підготовка майбутніх магістрів медицини в сучасних умовах стає предметом численних досліджень, що зумовлено підвищенням вимог до медиків як фрахівців в умовах кардинальних змін у суспільстві, отже, і до якості їхньої підготовки до самостійної педагогічної діяльності. У сучасній науці поняття «професійна підготовка» пов'язується із професійним навчанням і відображає процес опанування знань, умінь і навичок, необхідних для самостійної роботи за фрахом:

- система профресійного навчання, що має на меті прискорене набуття студентами навичок, необхідних для виконання певної роботи, групи робіт [5, с. 103];

- процес опанування знань, умінь і навичок, що дозволяють виконувати роботу в певній галузі діяльності [9, с. 282].

Однак підготовка до професійно-педагогічної діяльності не може обмежуватися опануванням майбутніми магістрами медицини лише процесуального аспекту педагогічної діяльності. Необхідна також цілеспрямована робота в напрямі формування і розвитку професійних, психологопедагогічних і особистісно значущих якостей майбутніх магістрів медицини, що забезпечуватимуть ефрективність обраної діяльності. Тому більш обґрунтоване розуміння професійної підготовки майбутніх фрахівців такої спеціальності як системи організаційних і педагогічних заходів, що забезпечує фрормування в магістрів медицини професійної спрямованості, знань, навичок, умінь і професійної готовності [12, с. 340].

Опираючись на окреслену позицію, профресійну підготовку майбутніх магістрів медицини розглядаємо як цілісну педагогічну систему, фрунціонування якої передбачає створення умов для розвитку особистості студентів на основі опанування необхідних для педагогічної діяльності знань, умінь і навичок, розвитку профресійно й особистісно значущих якостей, що забезпечують ефективність педагогічної діяльності.

У визначенні окресленого поняття передбачалося розуміння системи як внутрішньоорганізованого цілісного феномену, де всі елементи настільки тісно пов'язані один 3 одним, що виступають як щось єдине стосовно навколишніх умов та інших систем [10, с. 179], і педагогічної системи як безлічі взаємозалежних структурних компонентів, поєднаних єдиною освітньою метою розвитку особистості, функціонують у цілісному освітньому процесі [8, с. 11].

Як складна педагогічна система професійна підготовка майбутніх магістрів медицини до педагогічної діяльності має такі властивості, як: єдність і взаємозв'язок різних структурних елементів, поєднаних спільною метою і єдиним функціонуванням; єдина внутрішня організація на основі зв'язків і залежностей між компонентами системи, 
взаємодія 3 навколишнім середовищем. Виявлення структури педагогічної системи як відносно стійкого способу зв'язку елементів складного цілого, що відображає впорядкованість внутрішніх і зовнішніх зв'язків об'єкта та забезпечує його стійкість, стабільність, якісну визначеність [6, с. 43], представлено в сучасних наукових дослідженнях по-різному. Однак більшість науковців зазначають, що взаємозв'язок елементів - складників системи професійної підготовки студентів закладів вищої медичної освіти передбачає не просто їх групування і поєднання, а досягнення на основі їхньої інтеграції спільної мети - підготовки компетентного фрахівця. Ця мета і визначає структуру профресійної підготовки майбутніх магістрів медицини до педагогічної діяльності. Водночас важливим чинником такої системи є різноманітна за видами і змістом взаємопов'язана діяльність викладачів і студентів. Визначення мети професійної підготовки майбутніх магістрів медицини з урахуванням компетентнісного підходу, який є основою розвитку сучасної системи освіти, передбачає спрямованість навчання в медичних закладах вищої освіти (далі - МЗВО) на формування готовності студентів до ефективної педагогічної діяльності.

У площині осмислення проблеми структури педагогічної системи звертаємося до дослідження Н. Кузьміної, яка зазначає, що будь-яка педагогічна система має досить просту структуру, охоплює структурні та фрункціональні компоненти. Структурні компоненти (цілі, навчальна інфрормація (зміст), засоби педагогічної комунікації, викладачі і студенти) є основними базовими характеристиками педагогічних систем, сукупність яких і утворює такі системи [8, с. 13].

Структурний аналіз системи професійної підготовки майбутніх магістрів медицини зумовлює розкриття її змісту на основі визначення напрямів підготовки, що відображають їі цілісний характер і сприяють досягненню мети. Змістовний аспект професійної підготовки студентів МЗВО відображає взаємозв'язок особистісного та праксеологічного аспектів і охоплює такі компоненти, як: моральнопсихологічна, методологічна, теоретична, методична та практична підготовка, які перебувають у взаємозв'язку і взаємозалежності, забезпечують ефрективність фрункціонування такої системи.

Необхідним компонентом профресійної підготовки майбутніх магістрів медицини в контексті нашого дослідження $€$ морально-психологічна підготовка, яка передбачає фрормування в них професійно-педагогічної спрямованості особистості. Цей вид підготовки пов'язаний із розвитком ціннісних орієнтацій студентів, їхнього інтересу до педагогічної діяльності, профресійно й особистісно значущих якостей. Виокремлення методологічного компонента в системі профресійної підготовки майбутніх магістрів медицини зумовлено тим, що для фрормування педагогічної системи, як слушно зазначає М. Діанкіна, необхідна внутрішньодисциплінарна інтеграція емпіричного, методологічного і методичного знання в педагогіці, оскільки повний цикл педагогічної діяльності, що передбачає навчально-виховний аспект, розгортається за такою узагальненою схемою: практика (початковий рівень) - теоретичне знання (теорія) - методичне знання (методика) - практика (кінцевий рівень для даного циклу). Окрім того, на кожному етапі зазначеного циклу має фрункціонувати і методологічне знання, яке охоплює знання щодо способів вивчення педагогічної практики, накопичення необхідних емпіричних даних, способів сходження від емпіричних даних до теоретичних узагальнень, до побудови теорій; способів трансорормації теоретичних положень на мову конкретних методичних рекомендацій; знання способів упровадження відповідних рекомендацій у практику з метою іï перетворення, переведення на якісніший рівень, а також критеріїв і показників оцінки результативності педагогічної діяльності стосовно кожного циклу пізнання і перетворення педагогічної практики [7, с. 8-9].

У роботах, присвячених методології педагогіки, відзначається, що вона базується на вченнях про структуру, логічну організацію, методи та засоби діяльності у сорері теорії і практики [4, с. 100]. Так, Н. Батечко до методології відносить: соціальні цілі, гносеологічні та теоретичні положення фрілософії; понятійний фонд науки; знання про знання і незнання; методи педагогічних досліджень; принципи і методи педагогічного прогнозування; методи перетворення педагогічної дійсності; принципи ідеологічного аналізу педагогічних явищ і процесів; показники і критерії їх оцінки [2, с. 8]. 3 огляду на діяльнісний характер методології, уважаємо за доцільне доповнити це ще й організацією пізнавальної діяльності студентів із метою розвитку вміння користуватися наукою для осмислення і вдосконалення практичної педагогічної діяльності.

Профресійна підготовка студентів МЗВО до педагогічної діяльності передбачає й підготовку до методологічної діяльності, оскільки будь-яка діяльність здійснюється в межах певних правил, цільових настанов, зразків, технологічних розпоряджень тощо, а методологічна діяльність, за визначенням А. Агаркової [1, с. 7], спрямована на формування нових нормативів. Окрім того, методологічна діяльність сприяє подоланню внутрішньої і зовнішньої частковості діяльності, що особливо важливо в підготовці майбутніх магістрів медицини до організації цілісного освітнього процесу. У сучасних дослідженнях також підкреслюється, що орієнтація на засвоєння логічно завершеного, «готового» знання, переважання нормативності в підготовці майбутніх магістрів медицини спричиняє фрормування в них споживацького ставлення 
до науки [3, с. 61]. Отже, методологічна підготовка також $є$ необхідною складовою частиною професійної підготовки магістрів медицини до педагогічної діяльності.

Наступним компонентом авторської системи $є$ теоретична підготовка. У сучасних дослідженнях відзначається, що теоретична підготовка майбутніх магістрів медицини характеризується низкою недоліків, як-от: розрізненість окремих відомостей, описове засвоєння педагогічних понять, нерозуміння причинно-наслідкових зв'язків між педагогічними явищами, слабка сорормованість умінь обґрунтовувати теоретичні положення, їх застосування для аналізу педагогічних явищ [11, с. 90]. Для подолання таких недоліків необхідні зміни в курсі педагогіки, спрямовані на підвищення рівня використання теоретичних знань у практичній діяльності.

Важливим завданням підготовки студентів МЗВО до педагогічної діяльності $€$ їх озброєння сучасною педагогічною теорією на високому рівні систематизації й узагальнення, що передбачає знання закономірностей розвитку, навчання i виховання студентів, сутності і принципів цілісного освітнього процесу. Пізнання педагогічної теорії передбачає цілісне охоплення суті педагогічних явищ, усіх їхніх аспектів та взаємозв'язків, розгляд явищ у розвитку і тісному зв'язку з навколишньою дійсністю. Педагогічна теорія $€$ системою наукових знань щодо освітнього процесу, його сутності, закономірностей, форм і методів, озброює майбутніх магістрів медицини загальними методами пізнання і перетворення педагогічних явищ.

Система педагогічних знань охоплює провідні ідеї, поняття, основні фракти, закони тощо. Засвоєння педагогічних теорій відбувається у процесі спільного розвитку пізнавальної та предметнопрактичної діяльності майбутніх магістрів медицини і передбачає розуміння студентами суті основних педагогічних понять і категорій, у яких відображаються різні аспекти фрормування людської особистості. Основні педагогічні поняття становлять не лише фонд теоретичних знань, а й органічну частину педагогічного мислення студентів. Інтегровані теоретичні знання цілей і завдань цілісного педагогічного процесу, сутності, змісту, принципів, фрорм і методів освіти становлять основу профресійної педагогічної діяльності магістрів медицини. Це зумовлює значущість теоретичної підготовки студентів МЗВО в системі профресійної підготовки медиків до педагогічної діяльності.

У межах характеристики методичного аспекту підготовки студентів МЗВО до педагогічної діяльності необхідно зазначити таке. Якщо розглядати методику як методологію, спрямовану на фрормування програм діяльності [9, с. 267], то вона розглядається як наукова робота, спрямована на отримання нових продуктів - нових методів і засобів наукового дослідження [9, с. 317].
Профресійна підготовка студентів МЗВО передбачає озброєння майбутніх магістрів медицини не лише теорією, а й методикою здійснення освітнього процесу. Однак, якщо опанування методики виховного процесу органічно входить до складу педагогічної підготовки, то підготовка до здійснення освітнього процесу пов'язана з освоєнням методики викладання конкретної дисципліни за обраною спеціальністю. У такому разі помилково було б розглядати часткові методики як суто практичні, які здійснюють лише переклад теоретичних положень 3 інших наук на рівень їх практичного застосування, що узагальнюють спеціальні наукові та психолого-педагогічні знання.

Отже, розглядаємо методику викладання у МЗВО як самостійну дисципліну, у якій на основі загальнодидактичних закономірностей розкриваються специфічні завдання, принципи, зміст, форми і методи навчання конкретного наукового предмета. Курси методик озброюють студентів знанням завдань, принципів, конкретних фрорм і методів навчання студентів певної навчальної дисципліни, фоомування в них особистісних якостей засобами цієї дисципліни.

Оскільки підготовка студентів МЗВО до педагогічної діяльності стосується питань організації освітньої діяльності в навчальний та позанавчальний час, необхідне виокремлення методичної підготовки майбутніх магістрів медицини у відносно самостійний елемент у системі їх професійної підготовки до педагогічної діяльності. Це зумовлено також і тим, що повний цикл педагогічної діяльності, як зазначалося раніше, охоплює і методичний аспект. Тобто підготовка студентів МЗВО до педагогічної діяльності загалом і до конкретного іï виду передбачає методологічну, теоретичну і методичну підготовку.

На думку різних науковців, методична підготовка магістрів медицини до педагогічної діяльності визначається сукупністю знань щодо форм організації, методів і прийомів навчання [12, с. 350].

Ще одним структурним елементом системи профресійної підготовки студентів МЗВО є практична підготовка. Засвоєння знань нерозривно пов'язане 3 їх застосуванням на практиці, фрормуванням умінь і навичок здійснення педагогічної діяльності, що становить основу практичної підготовки майбутніх магістрів медицини. Практична підготовка до педагогічної діяльності передбачає формування педагогічних умінь і навичок, необхідних для вирішення педагогічних завдань в освітньому процесі. Вирішення такого завдання ґрунтується на положенні про те, що для організації будь-якої діяльності суб'єкту необхідно володіти високоспеціалізованими знаннями, оскільки будь-яка діяльність передбачає і технологічний компонент [5, с. 115]. Однак одного знання недостатньо, оскільки для ефективного 
здійснення діяльності потрібні відповідні вміння та навички у сорері технології і техніки діяльності. Сучасна наука визначає техніку як сукупність навичок і прийомів у будь-якій фрормі діяльності [2, с. 9], тобто опанування техніки діяльності $€$ необхідною умовою отримання високих результатів діяльності в будь-якій сфері. Усе це повною мірою стосується і педагогічної діяльності. Тоді як педагогічна техніка розглядається як комплекс знань, умінь і навичок, необхідних магістрам медицини для того, щоб ефективно застосовувати на практиці обрані методи педагогічного впливу на окремих студентів і групу загалом [10, с. 152]. Специфріка підготовки до педагогічної діяльності полягає в тому, що після закінчення МЗВО студенти стають самостійними організаторами освітнього процесу і повинні виконувати всі функції викладача. Тобто для підготовки компетентного викладача необхідна спеціальна практична підготовка магістрів медицини до педагогічної діяльності у процесі навчання у МЗВО.

3 огляду на це вважаємо за необхідне виокремити практичну підготовку у відносно самостійний компонент загальної системи профресійної підготовки майбутніх магістрів медицини до педагогічної діяльності. Це передбачає опанування студентами вмінь і навичок у галузі педагогічної техніки, способів і прийомів організації педагогічної взаємодії у процесі вирішення педагогічних завдань.

Висновки. Отже, структура системи підготовки майбутніх магістрів медицини до педагогічної діяльності охоплює морально-психологічну, методологічну, теоретичну, методичну та практичну підготовку. Окреслені складники відображають цілісний характер готовності до педагогічної діяльності і діалектичний взаємозв'язок його компонентів, що дає підставу розглядати їх як необхідні й достатні для збереження та розвитку системи підготовки магістрів медицини до педагогічної діяльності.

\section{БІБЛІОГРАФІЧНИЙ СПИСОК:}

1. Агаркова А. Формування профресійно-етичної культури майбутніх лікарів у вищих навчальних закладах : автореф. дис. ... канд. пед. наук: 13.00.07. Київ, 2011. 22 с.

2. Батечко Н. Синергетичний підхід до підготовки срахівців в умовах магістратури. Педагогічний процес: теорія і практика. 2012. Вип. 4. С. 5-15.

3. Наскрізна підготовка магістрів медицини з дисципліни «Педіатрія» / Т. Борисова та ін. Інноваціі у вищій медичній та фрармацевтичній освіті України (з дистанційним під'єднанням ВМ(Ф)НЗ України за допомогою відеоконференцзв'язку) : матеріали XVI Всеукраїнської науково-практичної конфреренції 3 міжнародною участю, м. Тернопіль, 16-17 травня 2019 р. Тернопіль : ТНМУ, 2019. С. 61.

4. Гуменюк О., Гуменюк В., Цюра С. Особливості підготовки магістрів у вищих медичних навчальних закладах України: наскрізна підготовка. Витоки педагогічної майстерності. 2017. Вип. 19. С. 96-102.

5. Делокаров К. Системная парадигма современной науки и синергетика. Общественные науки и современность. 2000. № 6. С. 110-118.

6. Демінська Л. Аналіз основних положень аксіологічної науки у фрілософському та педагогічному аспекті. Педагогіка, психологія та медико-біологічні проблеми фрізичного виховання і спорту. 2011. Вип. 11. С. 41-45.

7. Дианкина М. К вопросу формирования психолого-педагогической культуры в медицинском вузе. Ярославский психологический вестник. 2004. № 11. С. 7-10.

8. КузьминаН. Понятие «педагогической системы» и критерии ее оценки. Методы системного педагогического исследования / под. ред. Н. Кузьминой. Москва : Народное образование, 2002. С. 7-52.

9. Мачинська Н. Педагогічна освіта магістрантів вищих навчальних закладів непедагогічного профрілю : монографрія. Львів : ЛьвДУВС, 2013. 416 с.

10. Островская Л. Формирование педагогической культуры и этики в системе подготовки студентовмедиков : дис. ... докт. пед. наук: 13.00.01, 13.00.08. Москва, 2004. 325 с.

11. Стечак Г. Формування та розвиток педагогічної компетентності у студентів медичних закладів вищої освіти 3 використанням інноваційних технологій. Молодь і ринок. 2019. Вип. 11 (178). С. 88-94.

12. Cordella M. A triangle that may work well: Looking through the angles of a three-way exchange in cancer medical encounters. Discourse and Communication. 2011. Vol. 5 (4). P. 336-352. 